\title{
Effect of Unified Power Quality Conditioner on Voltage and Current Waveforms
}

\author{
Muhammad Ossama MAHMOUD ${ }^{1, *}$, Wael MAMDOUH ${ }^{2}$ and Hamdy KHALIL ${ }^{3}$ \\ ${ }^{I}$ Maintenance Manager, Giza Company for Water \& Wastewater (GCWW), Holding Company for Water \\ \& Wastewater (HCWW), Cairo, Egypt \\ ${ }^{2}$ Electrical Engineering Department, Egyptian Academy for Engineering and Advanced Technology, \\ EAE \& AT, Egypt \\ ${ }^{3}$ Department of Electrical Power and Machines, Faculty of Engineering, Ain-Shams University, Egypt
}

('Corresponding author's e-mail: eng_muhammad100@yahoo.com)

Received: 14 May 2020, Revised: 21 November 2020, Accepted: 20 December 2020

\begin{abstract}
Power quality improvement faces different and significant problems due to voltage instability and the wide use of electronic power devices. To overcome these different power quality problems, an active power filter is used. The active power filter, in general, has 4 main categories- shunt, series, unified power quality conditioner, and hybrid active power filter. The shunt active power filter is usually used to mitigate source current harmonics and compensate reactive power for power factor correction. The series active power filter is usually used to mitigate voltage problems (sags, swells, transients, dips, distortions, harmonics, etc.). The unified power quality conditioner is a combination of the shunt active power filter and the series active power filter; it is used to mitigate all voltage and current problems, compensate voltage, current system harmonics, and reactive power compensation, and mitigate voltage dips, voltage sags, voltage swells, and voltage phase shift. In this paper, the 3-phase 3-wire unified power quality conditioner is utilized to mitigate all power system problems (voltages and currents) and discuss the effect of the shunt and series active power filter separately on source voltage and source current waveforms. This case study shows that the source voltage distortion can be mitigated by using the series active power filter alone, but the source current distortion cannot be mitigated without using both the series and shunt active power filter. The source current harmonic problem mainly exists due to 1) distorted voltage sources, and 2) non-linear loads. Therefore, the unified power quality conditioner must be used to mitigate source current distortions in the case of the distorted voltage source, to comply with the standard limits IEEE 519, IEC 555, and IEC 61000.
\end{abstract}

Keywords: Series active power filter, Shunt active power filter, Unified power quality conditioner, Current harmonics, Voltage harmonics, Matlab/Simulink

\section{Introduction}

Power quality is a trending and highly important issue in electrical power systems. Power quality, in simple words, means the voltage quality generated and supplied to the entirety of an electrical power system [1-7]. It determines the fitness and health of the electrical power system. The main reasons for poor power quality are distortions in voltage and current waveforms. Distortion in voltage and current occurs because of voltage source problems (mains) and load problems (non-linear and unbalanced loads) [8]. The active power filter is one of the most effective solutions to overcome all power quality problems [9-16]. By using different categories of active power filters, the power quality improves, and customers will get pure sinusoidal voltage at the point of common coupling. Each category of active power filter mitigates specific power quality problems. The shunt active power filter, SHAPF, is usually used to 
mitigate load problems such as source current harmonics due to non-linear and the unbalanced load, power factor improvement, reactive power compensation, and voltage instability on the load side [17-22]. The series active power filter, SEAPF, is usually used to mitigate grid or mains problems, such as voltage sags, voltage swells, voltage dips, voltage unbalances, voltage interruptions, voltage phase shift, and voltage harmonics [23-37]. The unified power quality conditioner, UPQC, is utilized to solve all of the previous problems; this is called a universal active power filter and consists of a combination of shunt and series active power filters [38,39]. The hybrid active power filter is a combination of passive and active power filters and is used for high power applications [40-46]. As mentioned above, only the UPQC can mitigate all power quality problems. In this paper, a 3-phase 3-wire UPQC is used to mitigate all power quality problems and discuss the effect of SEAPF on source voltage and source current, and the effect of SHAPF on source voltage and source current. The system under study consists of a 3-phase distorted unbalanced voltage source supplying a non-linear balanced load. Source current harmonic component distortion will appear because of a distorted voltage source and non-linear loads. When applying SEAPF, the source voltage distortion is mitigated to match the standard limits, and the source current distortion is reduced but is still out of the standard limits. When applying SHAPF beside SEAPF, the source current distortion is mitigated to match the standard limits. The SEAPF is controlled to maintain voltage regulation and to eliminate supply voltage harmonics at the point of common coupling. The SHAPF is controlled to reduce the supply harmonic current, reactive power compensation, and load balancing.

The design and modeling of UPQC (SEAPF and SHAPF) for compensation of system harmonics and voltage controllers are discussed $[47,48]$.

\section{Materials and methods}

\section{System Architecture}

Series active power filter

The SEAPF is applied to act as a controlled voltage source. It reduces the terminal harmonic voltages, mitigates voltage dips, voltage sags, voltage harmonics, phase shift, and voltage swells, and supplies loads with a high-quality voltage waveform. The high impedance imposed by the SEAPF is created by generating a voltage of the same frequency to mitigate harmonic voltage distortion. Voltage unbalance is eliminated by compensating negative and 0 sequence voltage components of the system [49]. The operation principle, control strategy, and Matlab/Simulink results of the SEAPF are presented. Figure 1 shows the single line diagram of the 3-phase 3-wire SEAPF.

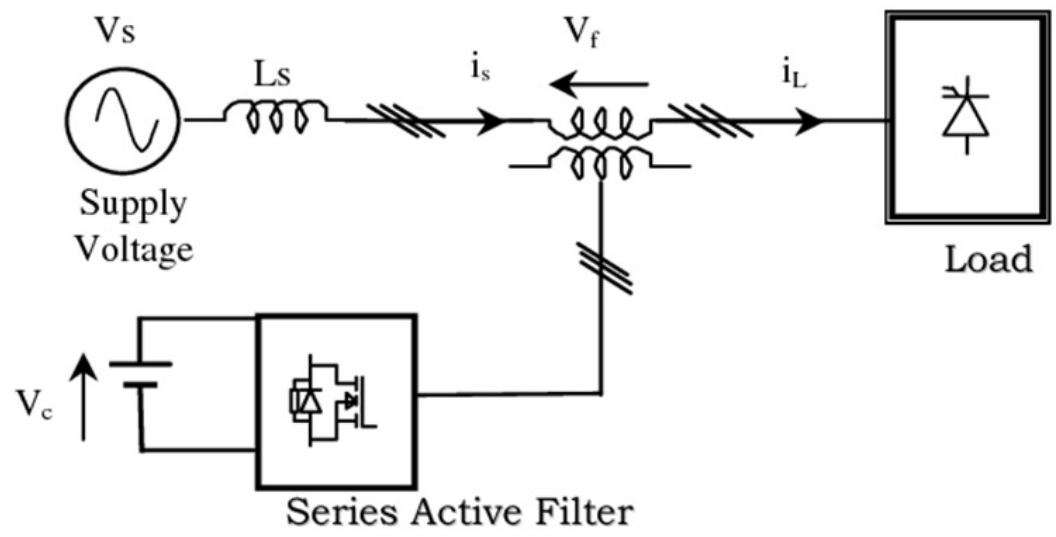

Figure 1 Single line diagram of 3-phase 3-wire SEAPF. 
The compensation characteristics of the SEAPF are mainly defined by the algorithm used to generate the reference signals required by the control system. These reference signals must allow current and voltage compensation with minimum time delay. The accuracy of the information contained in the reference signals must allow the elimination of the current harmonic and voltage unbalances present in the power system. Since the voltage and current control scheme are independent, the equations used to calculate the voltage reference signals are the following [50]:

$\left[\begin{array}{l}v_{a 0} \\ v_{a 1} \\ v_{a 2}\end{array}\right]=\frac{1}{\sqrt{3}}\left[\begin{array}{ccc}1 & 1 & 1 \\ 1 & a & a^{2} \\ 1 & a^{2} & a\end{array}\right]\left[\begin{array}{l}v_{a} \\ v_{b} \\ v_{c}\end{array}\right]$

where $\mathrm{a}=1 \angle-120$. All voltage related problems present in supply voltages are mitigated by controlling the SEAPF. The voltages $\mathrm{v}_{\mathrm{a}}, \mathrm{v}_{\mathrm{b}}$, and $\mathrm{v}_{\mathrm{c}}$ correspond to the phase voltages before the series transformer. The reference voltage signals are obtained by making the positive sequence component $\mathrm{v}_{\mathrm{a} 1}$, equal 0 , and then applying the inverse of the Fortescue transformation. In this way, the SEAPF compensates voltage unbalance. The reference signals for the voltage unbalance control scheme are obtained by applying the following equation:

$\left[\begin{array}{l}v_{\text {refa }} \\ v_{\text {ref } b} \\ v_{\text {ref } c}\end{array}\right]=\frac{1}{\sqrt{3}}\left[\begin{array}{ccc}1 & 1 & 1 \\ 1 & a^{2} & a \\ 1 & a & a^{2}\end{array}\right]\left[\begin{array}{c}-v_{a 0} \\ 0 \\ -v_{a 2}\end{array}\right]$

where $\mathrm{v}_{\mathrm{a} 0}$ is the 0 sequence components of voltage, and $\mathrm{v}_{\mathrm{a} 2}$ is the voltage negative sequence component [51].

The value of Rseries and Cseries of the SEAPF is as follows:

Rseries . Cseries $=\mathrm{Ts} / 10$.

where Rseries is the filter resistance, Cseries is the filter capacitance, and Ts is the switching time [49].

\section{Shunt active power filter}

The 3-phase 3-wire SHAPF based on the dc capacitor is shown in Figure 2. The SHAPF is a 3phase voltage source inverter (VSI) with a capacitor on the dc link. The SHAPF inverter is connected to the PCC through an interface coupling inductor. The SHAPF acts as a controlled current source delivering the load harmonic currents to the PCC. Consequently, the current absorbed from the grid at the PCC will be a pure sinusoidal waveform. A 3-phase insulated-gate bipolar transistor (IGBT) is used as voltage source inverter for harmonic elimination and power quality improvement.

This paper uses the p-q theory as a control method for SHAPF [52]. It is based on instantaneous values of 3-phase source voltage and 3-phase load current to obtain the active and reactive power required to be compensated. Two instantaneous powers are needed to be defined; the first is active power (p), and the second is reactive power $(\mathrm{q})$. 


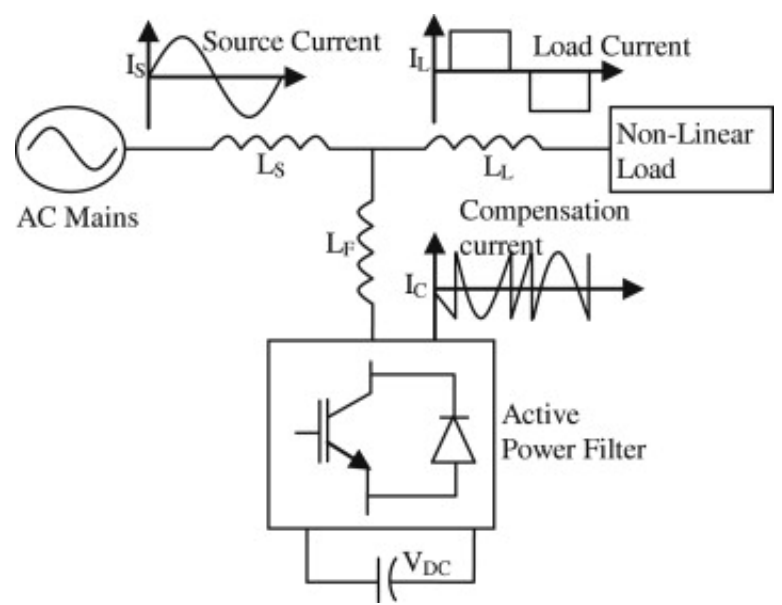

Figure 2 Configuration of 3-phase 3-wire SHAPF.

The calculations of these instantaneous power components are as follow:

$$
\begin{aligned}
& {\left[\begin{array}{l}
v_{\alpha} \\
v_{\beta}
\end{array}\right]=\sqrt{\frac{2}{3}}\left[\begin{array}{ccc}
1 & -1 / 2 & -1 / 2 \\
0 & \sqrt{3} / 2 & -\sqrt{3} / 2
\end{array}\right]\left[\begin{array}{l}
v_{a} \\
v_{b} \\
v_{c}
\end{array}\right]} \\
& {\left[\begin{array}{l}
i_{\alpha} \\
i_{\beta}
\end{array}\right]=\sqrt{\frac{2}{3}}\left[\begin{array}{ccc}
1 & -1 / 2 & -1 / 2 \\
0 & \sqrt{3} / 2 & -\sqrt{3} / 2
\end{array}\right]\left[\begin{array}{l}
i_{a} \\
i_{b} \\
i_{c}
\end{array}\right]} \\
& {\left[\begin{array}{l}
p \\
q
\end{array}\right]=\left[\begin{array}{cc}
v_{\alpha} & v_{\beta} \\
v_{\beta} & -v_{\alpha}
\end{array}\right]\left[\begin{array}{l}
i_{\alpha} \\
i_{\beta}
\end{array}\right]}
\end{aligned}
$$

The VSI is utilized to inject the compensating current into the grid. The gate pulses of the VSI are controlled due to the compensating currents from the SHAPF. Hysteresis current controller technique is used to control the VSI through the pulse width modulation to make the output current of the inverter track the reference current; the hysteresis current controller depends on 2 signals, the reference current signal and the output inverter current signal. The control circuit of the SHAPF produces the reference current, which is compared with the output inverter current. When the output inverter current increases out of the designed limits of the hysteresis band controller, the hysteresis band controller switches will be turned off and on [53].

The SHAPF parameters can be determined as follow:

Interfacing inductor $L_{S H}=\frac{V_{P C C}}{\omega H_{S H}} V_{S H}$.

where VPCC is voltage at the point of common coupling, VSH is VSI output voltage, and HsH is a hysteresis band of the SHAPF.

DC link capacitor $C_{d c}=\frac{S \cdot n \cdot T}{2 z V_{d c}^{23}}$.

where $\mathrm{S}$ is the required power to be compensated, $\mathrm{T}$ is the required time period for 1 complete cycle, $\mathrm{n}$ is the number of cycles for energy transfer, and $\mathrm{z}$ is the percentage of $\mathrm{V}_{\mathrm{dc}}$. 
$V_{d c}>\sqrt{3} \cdot V_{P C C-\max }$

The above parameters are the SHAPF design parameters [54].

\section{Matlab/Simulink model}

Figure 3 displays the Matlab/Simulink model for the system under study [55,56], which consists of a 3-phase distorted voltage source $\left(5^{\text {th }}\right.$ and $7^{\text {th }}$ harmonic orders are included, voltage sag, and voltage swell), a 3-phase RL non-linear load, a 3-Phase 3-wire SEAPF, a 3-phase 3-wire SHAPF connected to the system at the point of common coupling through a 3-phase circuit breaker, and measuring devices, as shown in Figure 3. The system components are listed in Table 1.

Table 1 System parameters.

\begin{tabular}{|c|c|c|}
\hline Component & Parameter & Value \\
\hline \multirow{5}{*}{ Voltage Source } & Voltage (line to line) rms & $380 \mathrm{~V}$ \\
\hline & Frequency & $50 \mathrm{~Hz}$ \\
\hline & Connection & Y neutral grounded \\
\hline & \multirow{2}{*}{$\begin{array}{c}\text { Order (n), Amplitude (pu) } \\
\text { Phase (degrees), Seq }(0,1 \text { or } 2)\end{array}$} & $\begin{array}{llll}5 & 0.2 & 0 & 2 \\
\end{array}$ \\
\hline & & $0.05 \quad 0$ \\
\hline \multirow{2}{*}{ Load } & 3 phase $\mathrm{R}$ & $15 \Omega$ \\
\hline & 3 phase $\mathrm{L}$ & $10 \mathrm{mH}$ \\
\hline \multirow{3}{*}{ SEAPF } & Inverter DC voltage & $\mathrm{VDC}=700 \mathrm{~V}$ \\
\hline & Series Resistance & Rseries $=1 \Omega$ \\
\hline & Series Capacitance & Cseries $=100 \mu \mathrm{F}$ \\
\hline \multirow{3}{*}{ SHAPF } & Inverter DC reference voltage & $\mathrm{V}_{\mathrm{DC}}=1200$ \\
\hline & $\mathrm{C}_{\mathrm{DC}}$ Capacitor & $\mathrm{Cf}=4700 \mu \mathrm{F}$ \\
\hline & Coupling Inductor & $\mathrm{Lf}=2 \mathrm{mH}$ \\
\hline
\end{tabular}

Figures 4 and $\mathbf{5}$ show the components of the SEAPF and SHAPF, respectively.

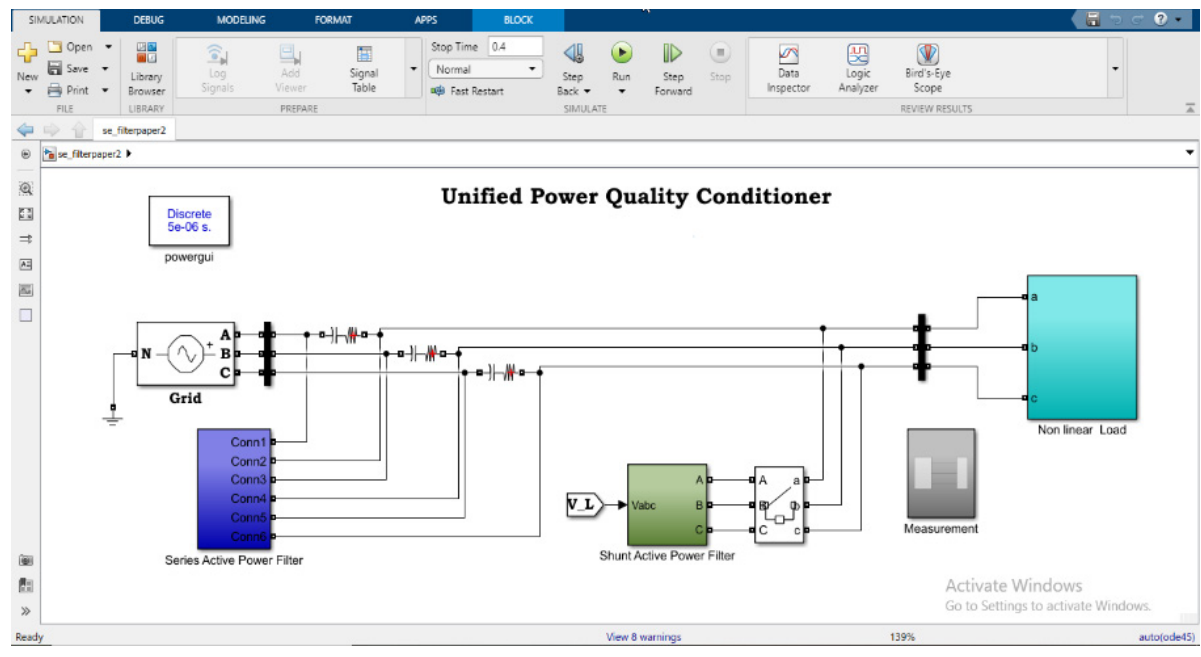

Figure 3 System Simulink model of power supply, UPQC, and nonlinear load. 
The simulation model shows the effect of the SEAPF and SHAPF on source voltage and source current waveforms. The overall simulation time is $0.25 \mathrm{~s}$. The simulation starts at $0 \mathrm{~s}$ with voltage amplitude value $=1 \mathrm{p}$.u, and at $\mathrm{t}=0.05 \mathrm{~s}$, the voltage sag value $=0.5 \mathrm{p} . \mathrm{u}$, and at $\mathrm{t}=0.1 \mathrm{~s}$, the voltage amplitude value $=1 \mathrm{p}$.u, and at $\mathrm{t}=0.15 \mathrm{~s}$, the voltage swell value $=1.5 \mathrm{p}$.u, and at $\mathrm{t}=0.2 \mathrm{~s}$, the voltage amplitude value $=1$ p.u.

Fifth and seventh voltage harmonic orders are generated throughout the simulation time.

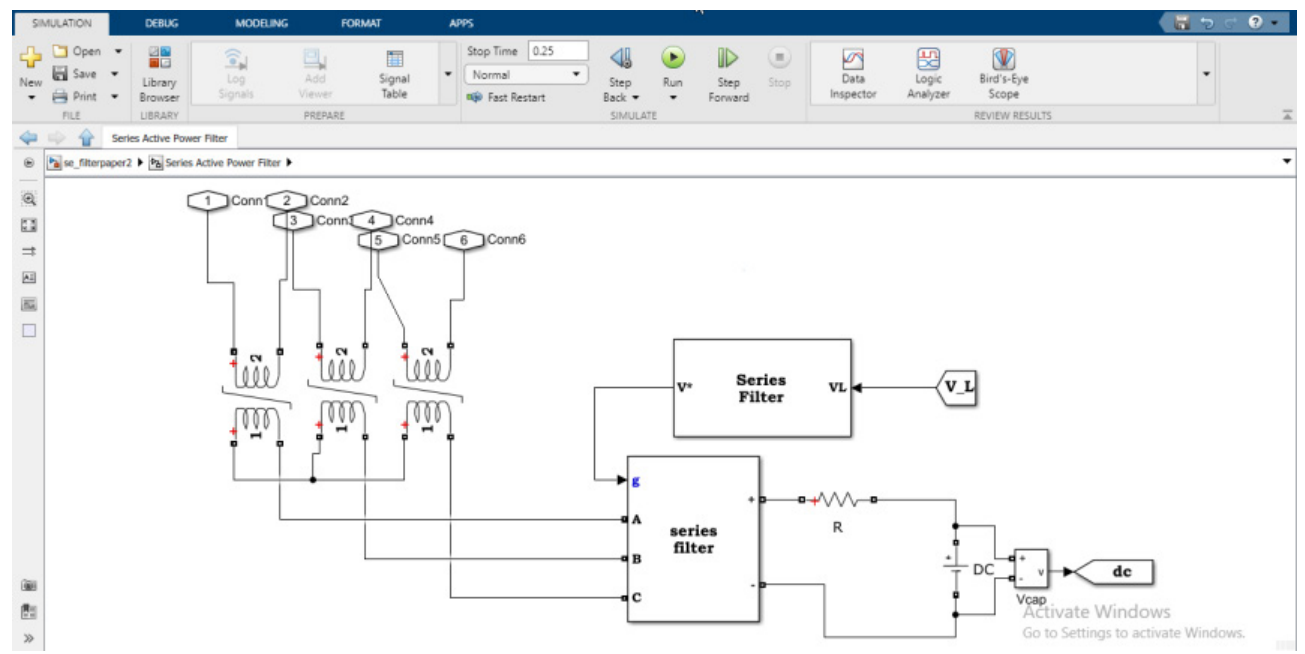

Figure 4 Simulink model of the SEAPF.

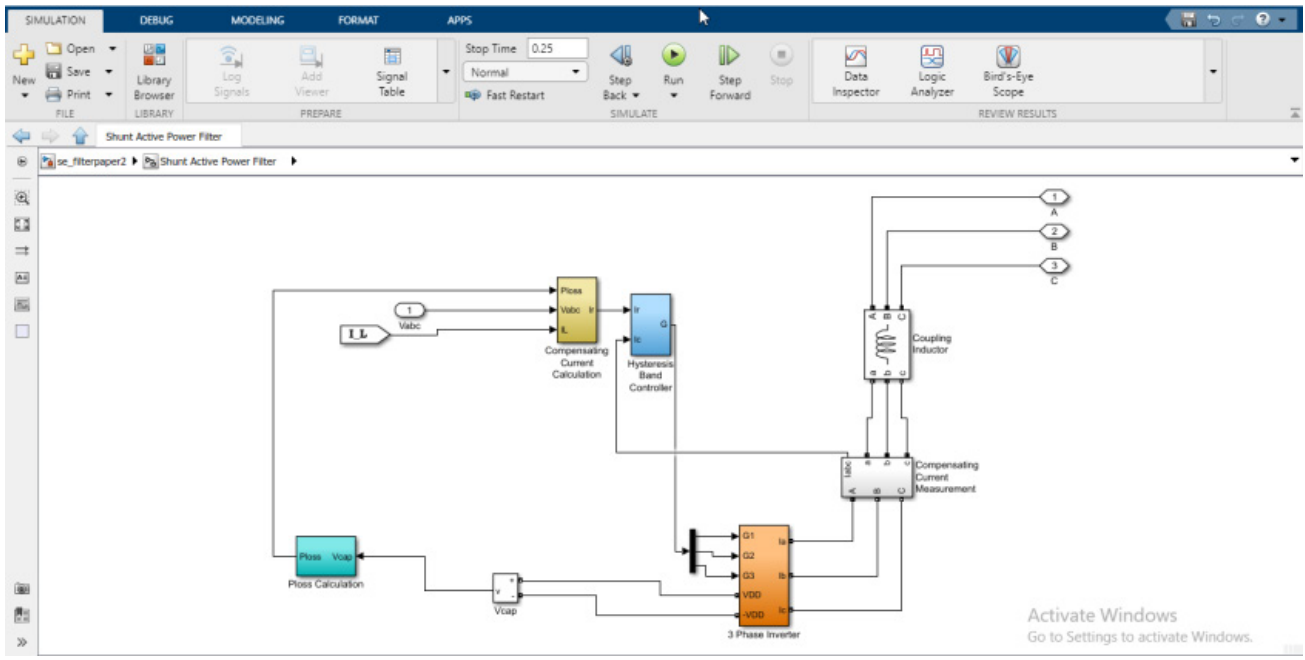

Figure 5 Simulink model of the SHAPF.

\section{Results and discussion}

3 case studies are presented to show the waveforms of source voltage and source current before and after connecting the SEAPF and SHAPF. Comparing these 3 cases show the effects of the SEAPF and SHAPF on mitigating the voltage and current problems, and on power quality improvement. 
Without connecting UPQC (SEAPF \& SHAPF)

In the first case study, the whole power system simulation model is run without connecting the UPQC. Figures 6 - 8 show distorted source voltage vs. distorted source current waveform, FFT analysis of source voltage, and FFT analysis of source current, respectively.
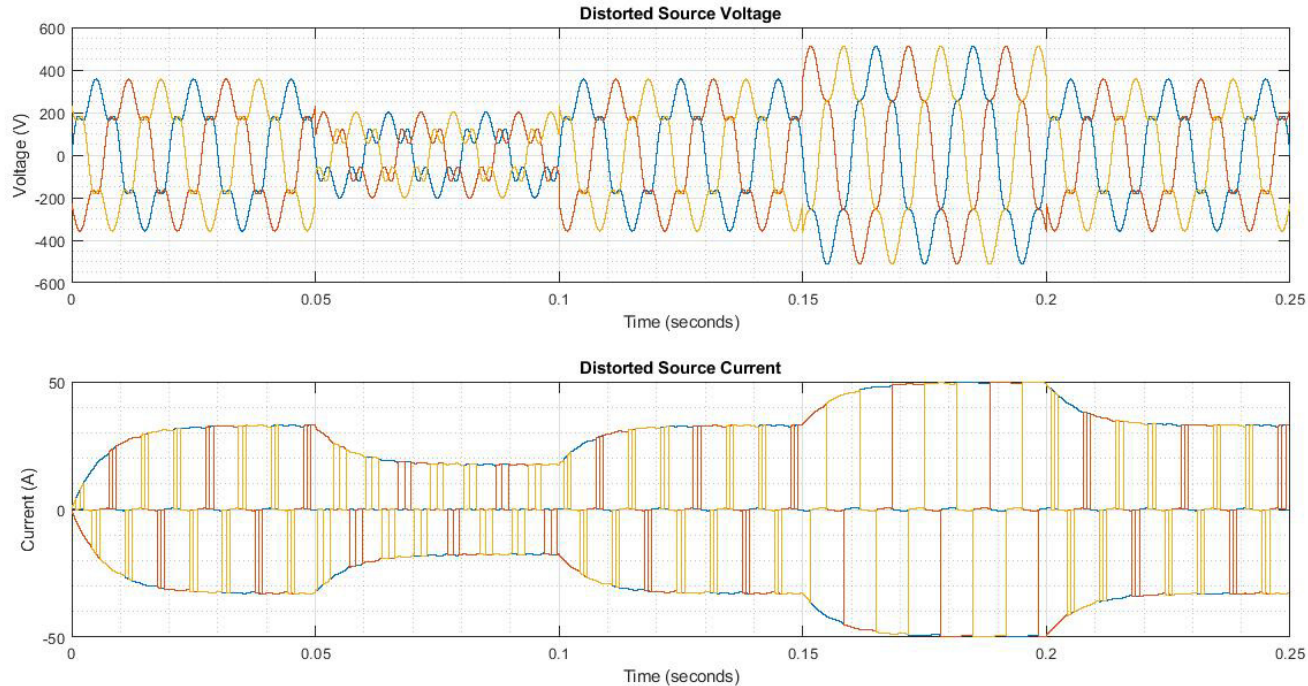

Figure 6 Source voltage vs. source current before connecting UPQC.

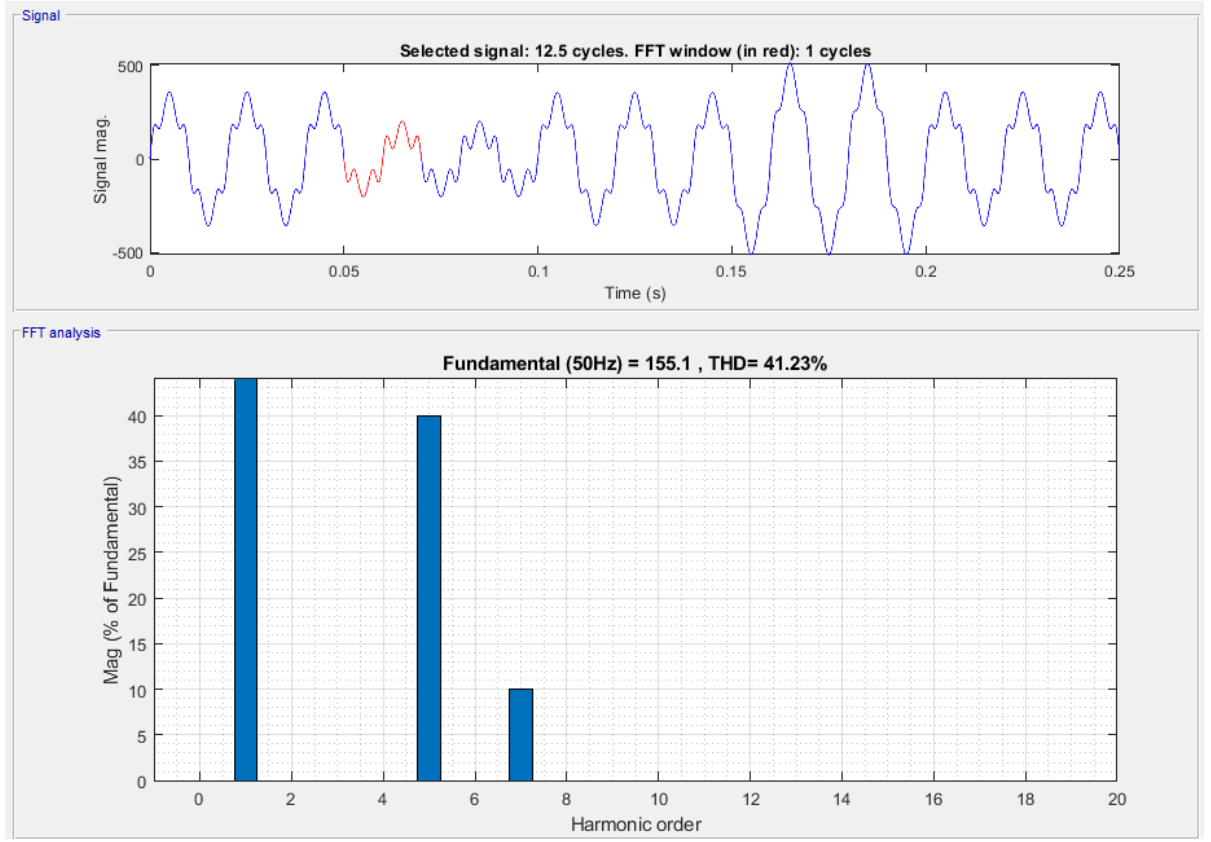

Figure 7 FFT analysis of distorted source voltage. 


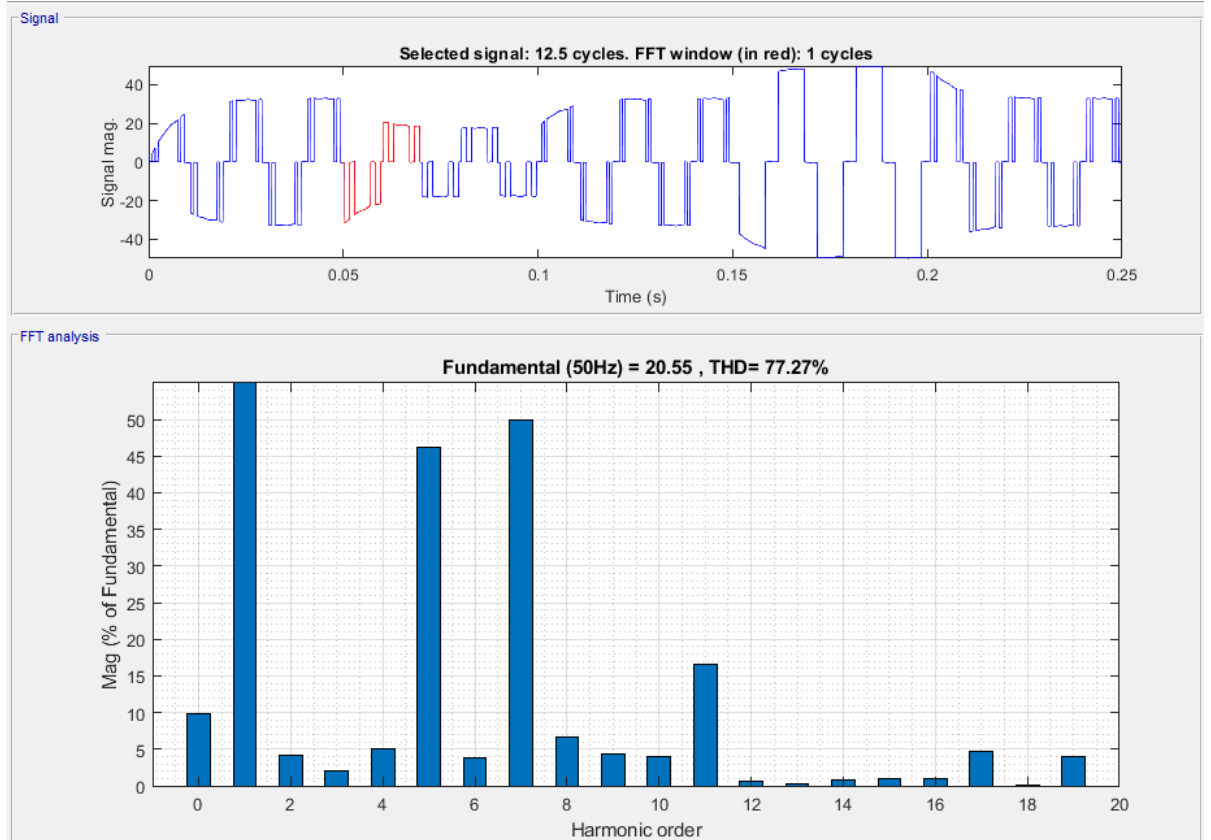

Figure 8 FFT analysis of distorted source current.

As shown in Figures 6 - 8, there is a great distortion in source voltage and source current. The source voltage is distorted because of sags, swells, harmonics, and the THD\% of the source voltage is $41.23 \%$; this $\mathrm{THD} \%$ of the source voltage is too high and is out of standard limits. The source current harmonic is distorted, and the THD\% of the source current is $77.27 \%$. The THD\% of source current is also too high because of the great distortion in source current due to 1) the distorted voltage source, 2) the non-linear load.

Table 2 shows the THD\% of the source voltage and source current before connecting the UPQC.

Table 2 THD\% of source voltage and source current.

\begin{tabular}{cc}
\hline Source Voltage THD\% & Source Current THD\% \\
\hline 41.23 & 77.27 \\
\hline
\end{tabular}

\section{With connecting SEAPF alone}

In the second case study, the whole power system simulation model is run with connecting the SEAPF alone (without connecting the SHAPF). Figures 9 - 11 show pure source voltage vs. SEAPF injected voltage vs. distorted source current waveforms, FFT analysis of source voltage, and FFT analysis of source current, respectively. 

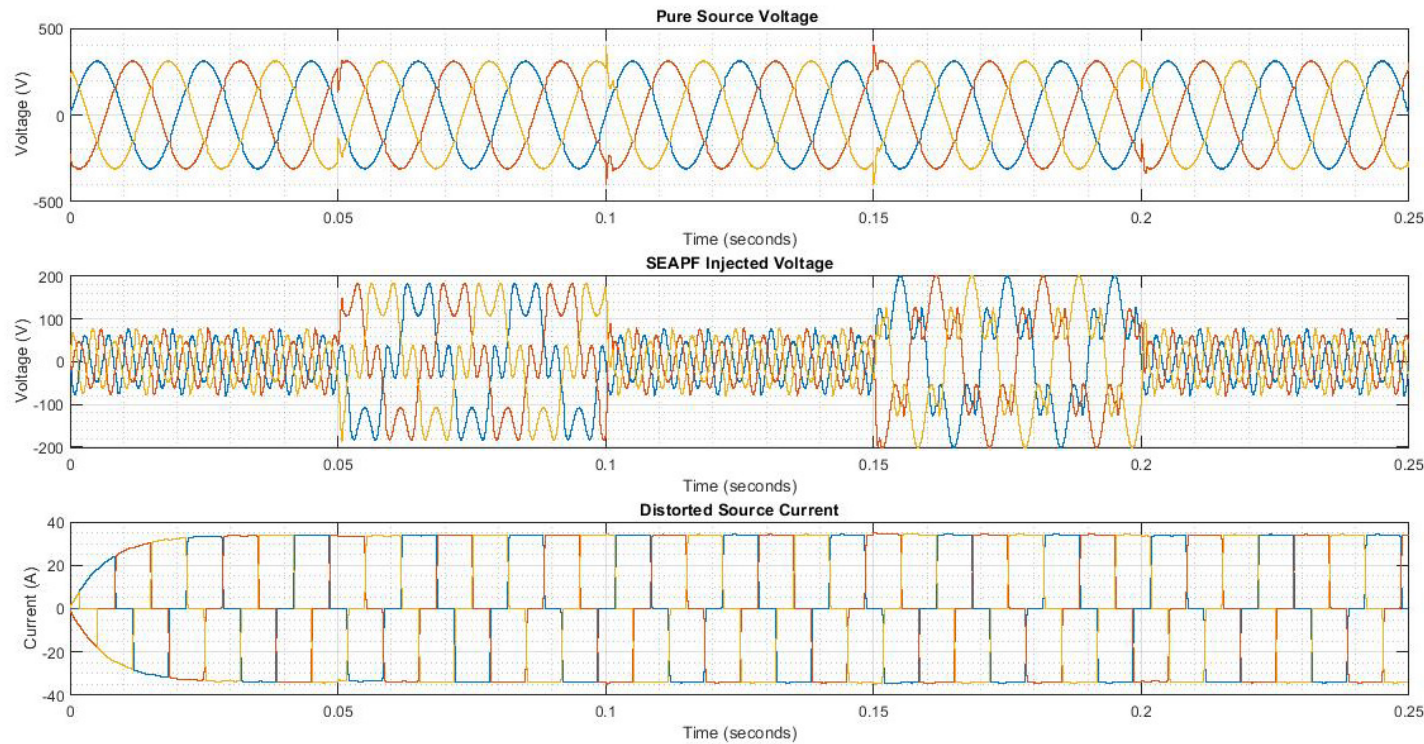

Figure 9 Source voltage vs. SEAPF injected voltage vs. source current.

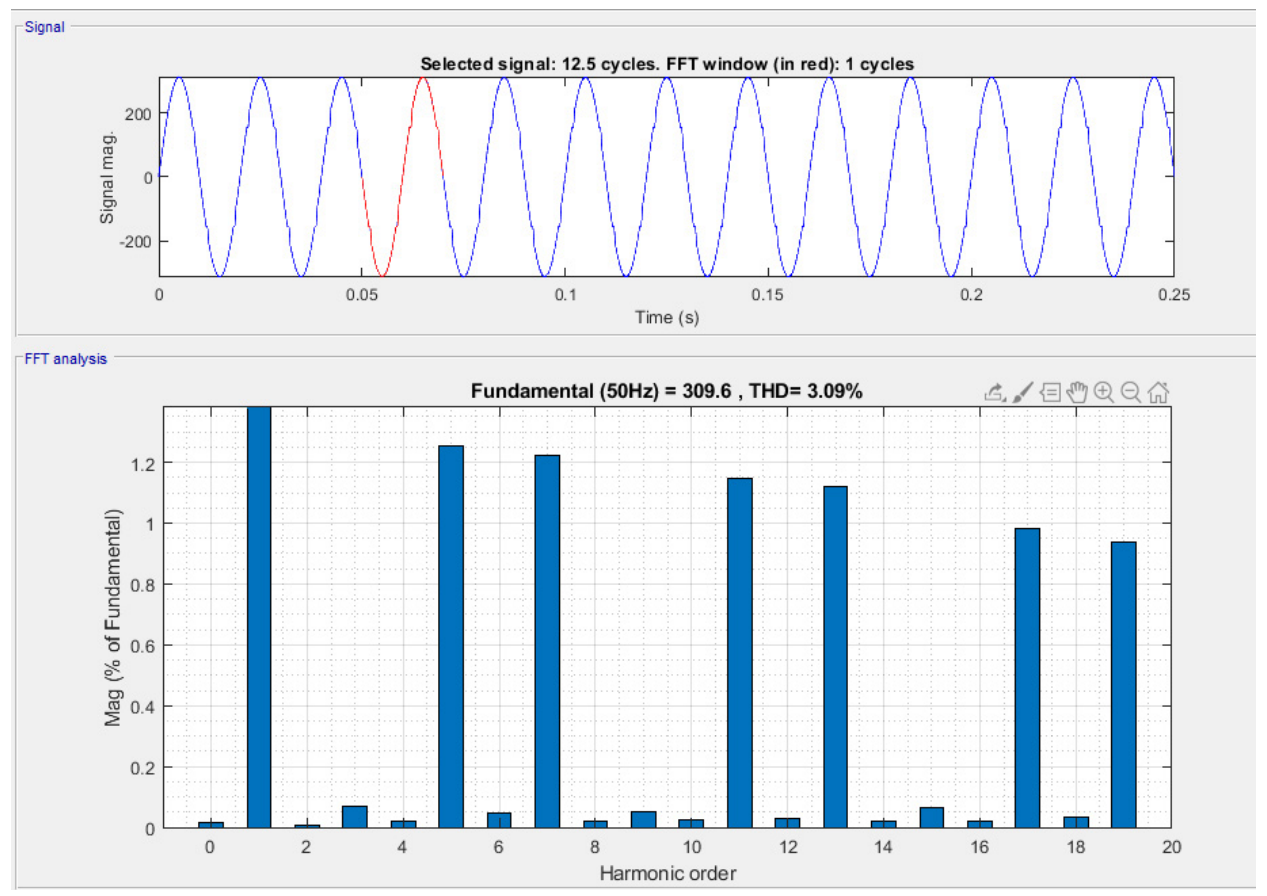

Figure 10 FFT analysis of pure source voltage. 


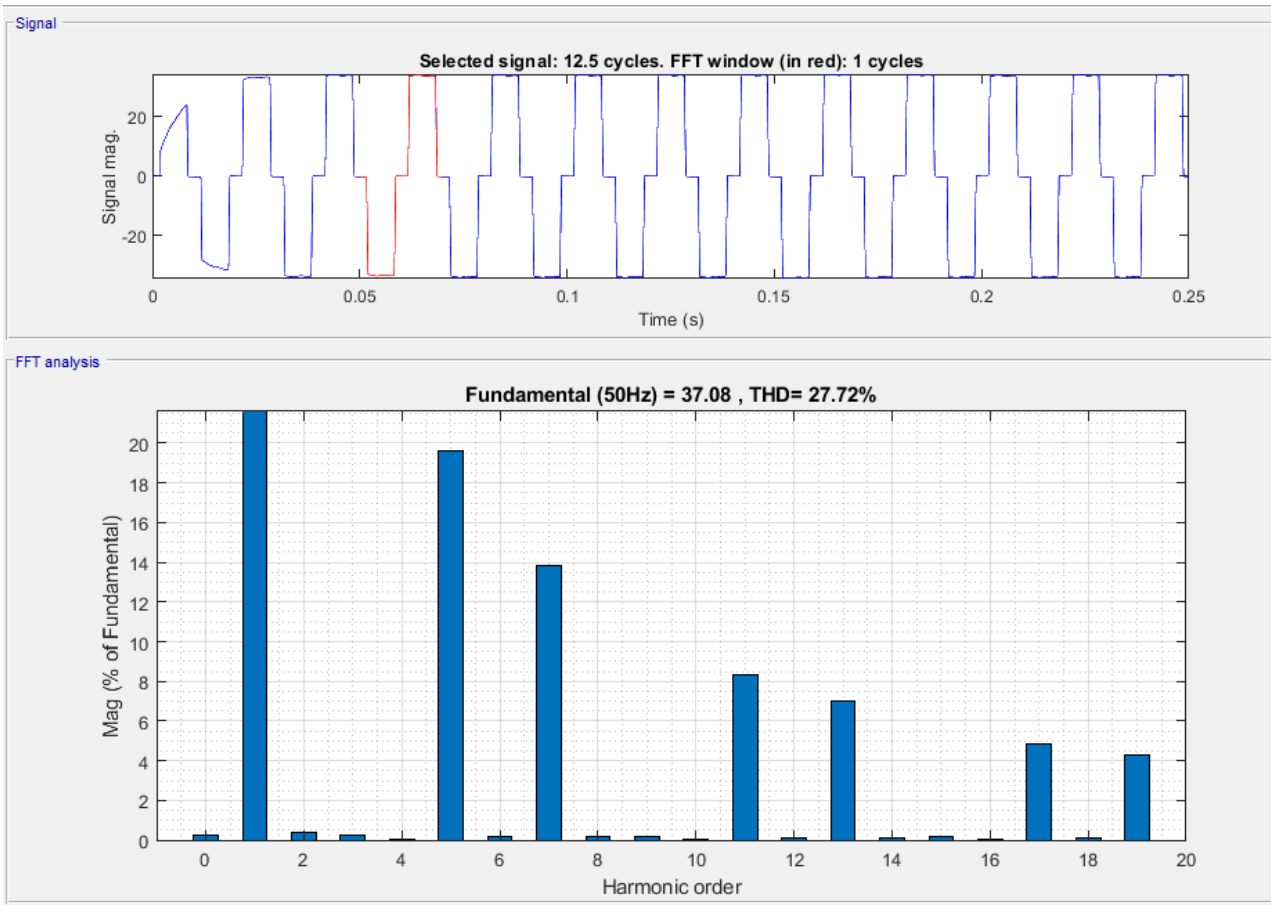

Figure 11 FFT analysis of distorted source current.

As shown in Figures 9 - 11, the SEAPF mitigates the distortion of source voltage and reduces the distortion of source current. The THD $\%$ of source voltage becomes $3.09 \%$, and the THD $\%$ of source current becomes $27.72 \%$. The THD \% of source voltage matches the standard limits, but the THD $\%$ of source current is still high and is beyond the standard limits.

Table 3 shows the THD\% of source voltage and source current after connecting the SEAPF.

Table 3 THD $\%$ of source voltage and source current.

\begin{tabular}{cc}
\hline Source Voltage THD\% & Source Current THD\% \\
\hline 3.09 & 27.72 \\
\hline
\end{tabular}

With connecting UPQC (SEAPF \& SHAPF)

In the third case study, the whole power system simulation model is run with connecting the UPQC (SEAPF \& SHAPF), the SEAPF is connected from the beginning of the simulation, and the SHAPF is connected through a circuit breaker at $t=0.2 \mathrm{~s}$. Figures 12 and 13 show pure source current vs. SHAPF injected current waveform, and FFT analysis of source current, respectively. 

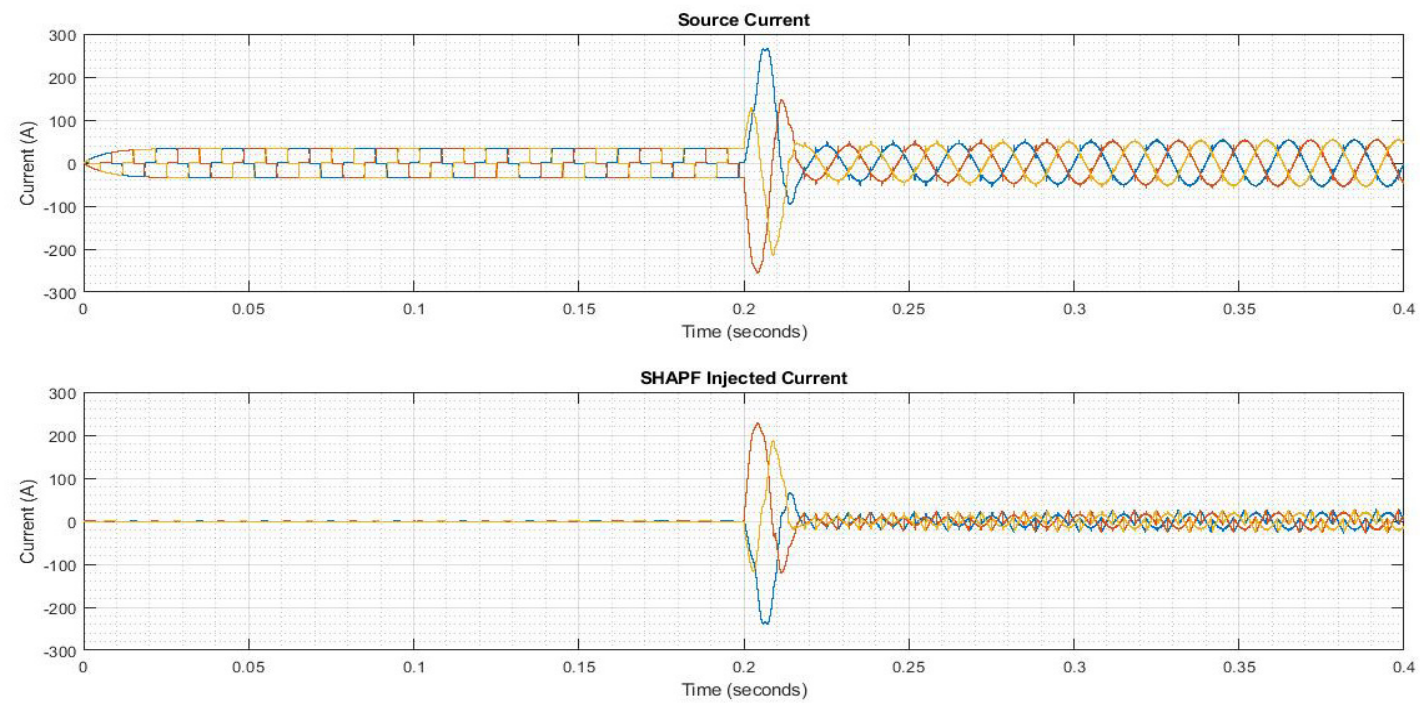

Figures 12 Source current vs. SHAPF injected current waveforms.

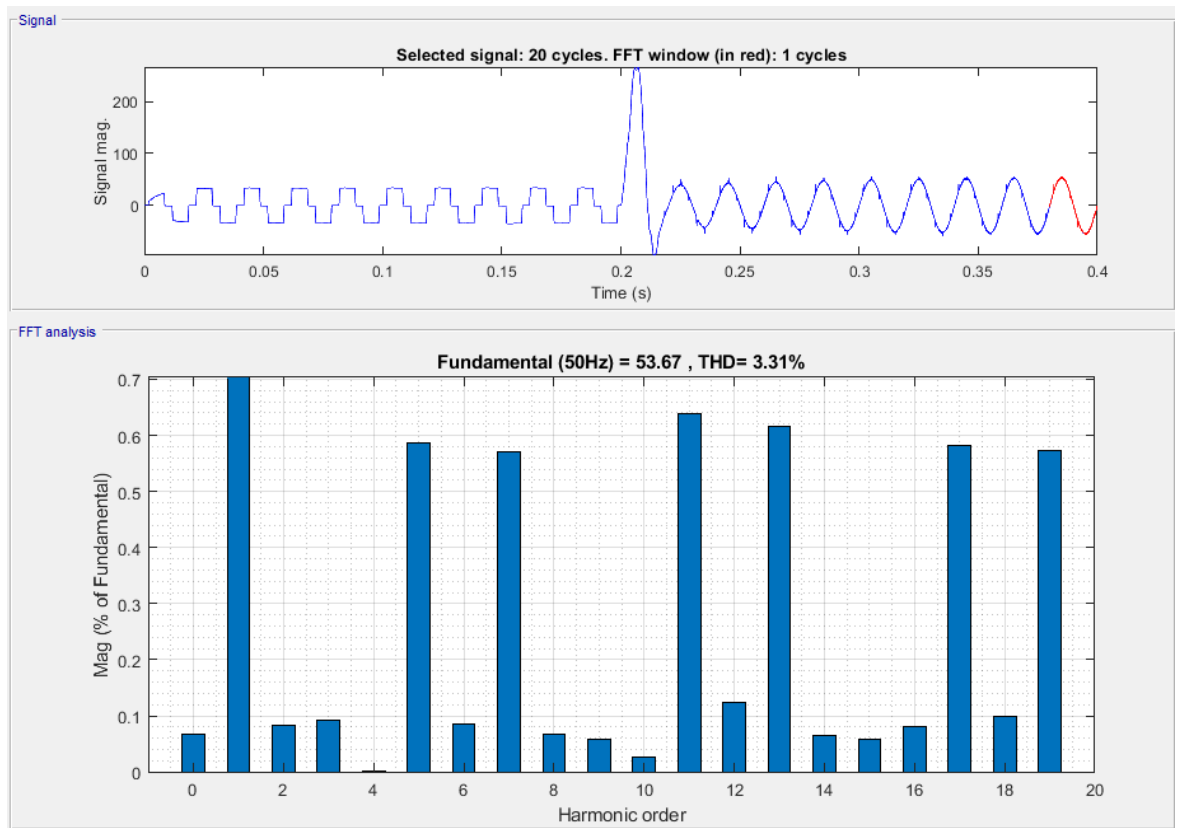

Figure 13 FFT analysis of pure source current.

After connecting the SHAPF, it is noticed that 1) the SHAPF has a good effect on source current harmonic elimination; 2) the THD\% of source current is within the standard limits; 3) the SHAPF does not have any effect on source voltage, and 4) the UPQC mitigates all power system problems. Table 4 shows the THD $\%$ of source voltage and source current after connecting the UPQC. 
Table 4 THD\% of source voltage and source current

\begin{tabular}{cc}
\hline Source Voltage THD\% & Source Current THD\% \\
\hline 3.09 & 3.31 \\
\hline
\end{tabular}

Table 5 shows a comparison of the THD $\%$ of source voltage and source current in the 3 cases.

Table 5 Comparison of THD\% of source voltage and source current.

\begin{tabular}{lccc}
\hline THD\% & $\begin{array}{c}\text { Before connecting } \\
\text { UPQC }\end{array}$ & $\begin{array}{c}\text { After connecting } \\
\text { SEAPF alone }\end{array}$ & $\begin{array}{c}\text { After connecting } \\
\text { SEAPF \& SHAPF }\end{array}$ \\
\hline Source Voltage THD\% & 41.23 & 3.09 & 3.09 \\
Source Current THD\% & 77.27 & 27.72 & 3.31 \\
\hline
\end{tabular}

\section{Conclusions}

The UPQC is used to mitigate all voltage and current problems and improve all power system quality. When using the UPQC, it is noticed that 1) the SEAPF eliminates all voltage problems, 2) the SEAPF reduces source current harmonics, but is still out of standard limits, 3) the SHAPF has no effect on source voltage, 4) the SHAPF eliminates source current harmonic distortion, and 5) the UPQC mitigates all power system problems. As shown in Table 5, the THD\% of source voltage and source current under distorted voltage source and non-linear load matches the standard limits [57-59].

\section{Acknowledgments}

I would like to express my deep gratitude and appreciation to Prof. Dr. Hamdy Saleh Khalil El Gohary, who chose the topic of the thesis, gave all required guidelines, and supported and assisted during the whole period of preparation of the thesis. Finally, I gratefully acknowledge and thank my parents and wife for their patience, understanding, and encouragement during the research period.

\section{References}

[1] MO Mahmoud, W Mamdouh and H Khalil. Source current harmonic mitigation of distorted voltage source by using shunt active power filter. Int. J. Electr. Comput. Eng. 2020; 10, 3967-77.

[2] F Harirchi and MG Simoes. Enhanced instantaneous power theory decomposition for power quality smart converter applications. IEEE Trans. Power Electro. 2018; 33, 9344-59.

[3] S Elphick, P Ciufo, G Drury, V Smith, S Perera and V Gosbell. Large scale proactive power-quality monitoring: An example from Australia. IEEE Trans. Power Deliv. 2017; 32, 881-9.

[4] S Singh, B Singh, G Bhuvaneswari and V Bist. Power factor corrected zeta converter based improved power quality switched mode power supply. IEEE Trans. Ind. Electron. 2015; 62, 542233.

[5] YJ Shin, EJ Powers, M Grady and A Arapostathis. Power quality indices for transient disturbances. IEEE Trans. Power Deliv. 2006; 21, 253-61.

[6] SK Dash and PK Ray. Power quality improvement utilizing PV fed unified power quality conditioner based on UV-PI and PR-R controller. CPSS Trans. Power Electron. Appl. 2018; 3, 24353.

[7] Q Xu, F Ma, A Luo, Z He and H Xiao. Analysis and control of M3C-based UPQC for power quality improvement in medium/high-voltage power grid. IEEE Trans. Power Electron. 2016; 31, 8182-94. 
[8] S Elphick, V Gosbell, V Smith, S Perera, P Ciufo and G Drury. Methods for harmonic analysis and reporting in future grid applications. IEEE Trans. Power Deliv. 2017; 32, 989-95.

[9] A Ullah, IUH Sheikh, S Arshad and F Saleem. Digital active power filter controller design for current harmonics in power system. In: Proceedings of the $16^{\text {th }}$ International Bhurban Conference on Applied Sciences \& Technology, Islamabad, Pakistan. 2019, p.384-8.

[10] S Devassy and B Singh. Control of solar energy integrated active power filter in weak grid system. In: Proceedings of the $7^{\text {th }}$ International Conference on Power Systems, Pune, India. 2017, p. 573-8.

[11] H Yuan and X Jiang. A simple active damping method for Active Power Filters. In: Proceedings of the IEEE Applied Power Electronics Conference and Exposition, Long Beach, USA. 2016, p. 90712.

[12] H Bai, X Wang and F Blaabjerg. A grid-voltage-sensorless resistive active power filter with series LC-filter. IEEE Trans. Power Electron. 2018; 33, 4429-40.

[13] M Ehtesham and M Jamil. Enhancement of power quality using active power filter for PV systems with model based MPPT. In: Proceedings of the $14^{\text {th }}$ IEEE India Council International Conference, Roorkee, India. 2017, p. 1-6.

[14] M Marcu, FG Popescu, T Niculescu, L Pana and AD Handra. Simulation of power active filter using instantaneous reactive power theory. In: Proceedings of the $16^{\text {th }}$ International Conference on Harmonics and Quality of Power, Bucharest, Romania. 2014, p. 581-5.

[15] N Chen, S Yu, L Gao, Y Huang and R Chen. Suppressing interference peak in an active power filter via periodic carrier frequency modulation based on a spectrum analysis approach. IEEE Trans. Electromagn. C. 2017; 61, 1760-70.

[16] JK Zadeh and E Farjah. New control technique for compensation of neutral current harmonics in three-phase four-wire systems. In: Proceedings of the IEEE Bucharest PowerTech, Bucharest, Romania. 2009, p. 1-6.

[17] SS Patil, RA Metri and OK Shinde. Shunt active power filter for MV 12-pulse rectifier using PI with SMC controller. In: Proceedings of the International Conference on Circuit, Power, and Computing Technologies, Kollam, India. 2017, p. 1-6.

[18] SA Taher, MH Alaee and ZD Arani. Model predictive control of PV-based shunt active power filter in single phase low voltage grid using conservative power theory. In: Proceedings of the $8^{\text {th }}$ Power Electronics, Drive Systems \& Technologies Conference, Mashhad, Iran. 2017, p. 253-8.

[19] M Buyuk, A Tan, M Inci and M Tumay. A notch filter based active damping of llcl filter in shunt active power filter. In: Proceedings of the International Symposium on Power Electronics, Novi Sad, Serbia. 2017, p. 1-6.

[20] K Vibhute. Efficient shunt active power filter for harmonic suppression: A Matlab/Simulink approach. In: Proceedings of the International Conference on Computer, Communication and Control, Indore, India. 2015, p. 1-5.

[21] SS Patil and RA Metri. Power quality improvement using shunt active power filter. In: Proceedings of the International Conference on Data Management, Analytics, and Innovation, Pune, India. 2017, p. 152-6.

[22] S Gautam and M Aeidapu. Sine cosine algorithm based shunt active power filter for harmonic compensation. In: Proceedings of the $3^{\text {rd }}$ International Conference on Electronics, Communication, and Aerospace Technology, Coimbatore, India. 2019, p. 1051-6.

[23] P Salmerón and SP Litrán. Improvement of the electric power quality using series active and shunt passive filters. IEEE Trans. Power Deliv. 2010; 25, 1058-67.

[24] J Gholinezhad and N Aghli. A new control strategy for series active filter to improve low-frequency oscillations damping. In: Proceedings of the $21^{\text {st }}$ Electrical Power Distribution Conference, Karaj, Iran. 2016, p. 161-7.

[25] JL Torre, LAM Barros, JL Afonso and JG Pinto. Development of a proposed single-phase series active power filter without external power sources. In: Proceedings of the International Conference on Smart Energy Systems and Technologies, Porto, Portugal. 2019, p. 1-6. 
[26] HF Hashim, R Omar and M Rasheed. Design and analysis of a three phase series active power filter (SAPF) based on hysteresis controller. In: Proceedings of the $4^{\text {th }}$ IET Clean Energy and Technology Conference, Kuala Lumpur, Malaysia. 2016, p. 1-5.

[27] Z Pan, FZ Peng and S Wang. Power factor correction using a series active filter. IEEE Trans. Power Electron. 2005; 20, 148-53.

[28] ER Ribeiro and I Barbi. Harmonic voltage reduction using a series active filter under different load conditions. IEEE Trans. Power Electron. 2006; 21, 1394-402.

[29] S Inoue, T Shimizu and K Wada. Control methods and compensation characteristics of a series active filter for a neutral conductor. IEEE Trans. Ind. Electron. 2007; 54, 433-40.

[30] LFJ Meloni, FL Tofoli, AJJ Rezek and ER Ribeiro. Modeling and experimental validation of a single-phase series active power filter for harmonic voltage reduction. IEEE Access 2019; 7, 151971-84.

[31] GM Lee, DC Lee and JK Seok. Control of series active power filters compensating for source voltage unbalance and current harmonics. IEEE Trans. Ind. Electron. 2004; 51, 132-9.

[32] A Ravikumar, N Mohan and K Soman. Performance enhancement of a series active power filter using kalman filter based neural network control strategy. In: Proceedings of the International Conference on Advances in Computing, Communications and Informatics, Bangalore, India. 2018, p. 1702-6.

[33] X Chen, T Wang, H Wang, Y Hou and L Gua. A magnetic flux compensated series active power filter using deadbeat control based on repetitive predictor theory. In: Proceedings of the $22^{\text {nd }}$ International Conference on Electrical Machines and Systems, Harbin, China. 2019. p. 1-5.

[34] BR Khade and VB Virulkar. Mitigation of harmonics in a neutral conductor for three-phase fourwire distribution system using series active power filter. In: Proceedings of the IEEE International Conference on Electrical, Computer and Communication Technologies, Coimbatore, India. 2015, p. 1-6.

[35] MA Chaudhari and Chandraprakash. Three-phase series active power filter as power quality conditioner. In: Proceedings of IEEE International Conference on Power Electronics, Drives and Energy Systems, Bengaluru, India. 2012, p. 1-6.

[36] HF Hashim, R Omar and M Rasheed. Design and analysis of a three phase series active power filter (SAPF) based on hysteresis controller. In: Proceedings of the $4^{\text {th }}$ IET Clean Energy and Technology Conference, Kuala Lumpur, Malaysia. 2016, p. 1-5.

[37] B Toth and Z Puklus. Series active filters: Spice simulation. In: Proceedings of the $11^{\text {th }}$ International Symposium on Computational Intelligence and Informatics, Budapest, Hungary. 2010.

[38] JK Lee, JK Seok and DC Lee. Unified active power filters for source voltage unbalance/current harmonics compensation and power factor correction. In: Proceedings of the $30^{\text {th }}$ Annual Conference of IEEE Industrial Electronics Society, Busan, South Korea. 2004, p. 540-5.

[39] K Nohara, A Ueda, A Torii and K Doki. Compensating characteristics of a series-shunt active power filter considering unbalanced source voltage and unbalanced load. In: Proceedings of the Power Conversion Conference, Nagoya, Japan. 2007, p. 1692-7.

[40] B Chen, C Zhang, C Tian, J Wang and J Yuan. A hybrid electrical magnetic power quality compensation system with minimum active compensation capacity for $\mathrm{V} / \mathrm{V}$ cophase railway power supply system. IEEE Trans. Power Electron. 2016; 31, 4159-70.

[41] D Daftary and MT Shah. Design and analysis of hybrid active power filter for current harmonics mitigation. In: Proceedings of the IEEE $16^{\text {th }}$ India Council International Conference, Rajkot, India. 2019, p. 1-4.

[42] S Rahmani, A Hamadi, K Al-Haddad and LAA Dessaint. Combination of shunt hybrid power filter and thyristor-controlled reactor for power quality. IEEE Trans. Ind. Electron. 2014; 61, 2152-64.

[43] B Kedra. Reducing inverter power rating in active power filters using proposed hybrid power filter topology. In: Proceedings of the IEEE $15^{\text {th }}$ International Conference on Environment and Electrical Engineering, Rome, Italy. 2015, p. 443-8. 
[44] A Cleary-Balderas, A Medina-Rios and O Cruz-Hernéndez. Hybrid active power filter based on the IRP theory for harmonic current mitigation. In: Proceedings of the IEEE International Autumn Meeting on Power, Electronics and Computing, Ixtapa, Mexico. 2016, p. 1-5.

[45] A Javadi, A Hamadi, L Woodward and K Al-Haddad. Experimental investigation on a hybrid series active power compensator to improve power quality of typical households. IEEE Trans. Ind. Electron. 2016; 63, 4849-59.

[46] YW Wang, MC Wong and CS Lam. Historical review of parallel hybrid active power filter for power quality improvement. In: Proceedings of the TENCON, IEEE Region 10 Conference, Macao, China. 2015, p. 1-6.

[47] SS Bhosale, YN Bhosale, UM Chavan and SA Malvekar. Power quality improvement by using UPQC: A review. In: Proceedings of the International Conference on Control, Power, Communication and Computing Technologies, Kannur, India. 2018, p. 375-80.

[48] N Karelia, AV Sant and V Pandya. Comparison of UPQC topologies for power quality enhancement in grid integrated renewable energy sources. In: Proceedings of the IEEE $16^{\text {th }}$ India Council International Conference, Rajkot, India. 2019, p. 1-4.

[49] A Sharma, SK Sharma and B Singh. Unified power quality conditioner analysis design and control. In: Proceedings of the IEEE Industry Applications Society Annual Meeting, Portland, USA. 2018, p. $1-8$.

[50] KP Kumar and K Ilango. Design of series active filter for power quality improvement. In: Proceedings of the International Conference on Electronics, Communication and Computational Engineering, Hosur, India. 2014, p. 78-82.

[51] YS Kim, JS Kim and SH Ko. Three-phase three-wire series active power filter, which compensates for harmonics and reactive power. IEE Proc. Elec. Power Appl. 2004; 151, 276-82.

[52] A Panchbhai, S Parmar and N Prajapati. Shunt active filter for harmonic and reactive power compensation using p-q theory. International In: Proceedings of the Conference on Power and Embedded Drive Control, Chennai, India. 2017, p. 260-4.

[53] S Jena, B Mohapatra, CK Panigrahi and SK Mohanty. Power quality improvement of 1- $\varphi$ grid integrated pulse width modulated voltage source inverter using hysteresis Current Controller with offset band. In: Proceedings of the $3^{\text {rd }}$ International Conference on Advanced Computing and Communication Systems, Oimbatore, India. 2016, p. 1-7.

[54] SK Khadem, M Basu and MF Conlon. Harmonic power compensation capacity of shunt APF and its relationship to design parameters. IET Power Electron. 2014; 7, 418-30.

[55] G Rajpriya, S Ravi and AMA Zaidi. Design and development of MATLAB simulink based selective harmonic elimination technique for three phase voltage source inverter. In: Proceedings of the International Conference on Advanced Computing and Communication Systems, Coimbatore, India. 2013, p. 1-5.

[56] MathWorks Inc. Simulink: The dynamic system simulation software-user's guide. MathWorks Inc, Massachusetts, 1993.

[57] 519-1992 - IEEE Recommended Practices and Requirements for Harmonic Control in Electrical Power Systems.

[58] IEC 555 part 2-harmonics: Background and implications.

[59] EN/IEC 61000-3-2 harmonic analyzer evaluations. 